\title{
Identification of Appropriate Biodiversity Indicators for Ecologically Sustainable Forest Management at National Level
}

\author{
(Pengenalpastian Penunjuk Kepelbagaian Biologi Sesuai untuk Pengurusan Hutan Mampan
} daripada Segi Ekologi di Peringkat Kebangsaan)

AHMET TOLUNAY* \& AYHAN AKYOL

\begin{abstract}
Sustainable forest management (SFM) practices have started in 1999 in Turkey. A set of criteria and indicators, composed by the General Directorate of Forestry (GDF) on the basis of the criteria and indicators defined in the Pan-European and Near Eastern Processes, was enquired via a survey to serve this purpose. GDF tested the sustainability under the following titles: Situation of forest resources, biodiversity, health and vitality, production capacity and functions, protective functions and environmental and socio-economic functions. There were problems in identification and definition of SFM criteria and indicators. Biological diversity indicators has been selected, described and developed in this study. At this phase, the survey was completed upon receiving the views of the scientists interested in different dimensions of this topic as well as the views of other interest groups affiliated with forestry. As a result, there were 13 indicators that may be used as the basis of a regional or forest management unit level for the purpose of protecting, developing and maintaining biodiversity. Furthermore, these indicators are instruments, which may easily be used by relevant decision-makers in the management of forest resources in a more effective and productive manner.
\end{abstract}

Keywords: Biodiversity; ecological sustainability; forest resources; indicators; natural resource management; sustainable forest management

\section{ABSTRAK}

Amalan pengurusan hutan mampan (SFM) telah dimulakan pada tahun 1999 di Turki. Satu set kriteria dan petunjuk, digubah oleh Direktorat Jeneral Perhutanan (GDF) berasaskan kriteria dan petunjuk yang ditakrifkan dalam proses Pan-Eropah dan Timur berhampiran, diperoleh melalui kaji selidik untuk tujuan ini. GDF menguji ketahanan di bawah tajuk berikut: Situasi sumber hutan, kepelbagaian biologi, kesihatan dan kecergasan, kapasiti pengeluaran dan fungsi, fungsi perlindungan dan alam sekitar serta fungsi sosio-ekonomi. Terdapat masalah dalam pengenalpastian dan definisi kriteria dan petunjuk SFM. Petunjuk kepelbagaian biologi telah dipilih, diterang dan dibangunkan dalam kajian ini. Pada fasa ini, kaji selidik tersebut telah selesai setelah menerima pandangan daripada para saintis yang berminat dalam dimensi yang berbeza bagi topik ini serta pandangan kumpulan berkepentingan yang lain berkaitan perhutanan. Hasilnya, terdapat 13 penunjuk yang boleh digunakan sebagai asas serantau atau peringkat unit pengurusan hutan untuk tujuan melindungi, membangunkan dan mengekalkan kepelbagaian biologi. Di samping itu, petunjuk ini adalah instrumen yang boleh digunakan dengan mudah oleh pihak pembuat keputusan dalam pengurusan sumber hutan dengan cara yang lebih efektif dan produktif.

Kata kunci: Kepelbagaian biologi; pembangunan mapan ekologi; pengurusan hutan mampan; pengurusan sumber alam; petunjuk; sumber hutan

\section{INTRODUCTION}

Sustainable forest management (SFM) criteria and indicators have become an important tool used for measuring the sustainability of forests, since the 90's when they have been added to the global forestry literature until today (Mendoza \& Prabhu 2000), although the concept has a long tradition of over two centuries (Farrell et al. 2000; Wiersum 1995). The criteria and indicators were first developed by the International Tropical Timber Association (ITTO) in 1992 in relation with tropical forests (ITTO 2005, 1992). In the Rio Summit convened in the same year, emphasis was made on the importance of SFM criteria and indicators for the implementation of the decisions adopted and the agreements signed, as well as monitoring and reporting developments (Castañeda et al. 2001; McDonald \& Lane 2004; Rametsteiner 2001; Wolfslehner et al. 2005).

The main objectives in international meetings and studies were to designate the criteria and indicators and serve the common purposes of the users with common definitions in the monitoring, evaluating, reporting and policy-development processes (Brand 1997; Brang et al. 2002; Mrozek et al. 2006; Purnomo et al. 2004). These objectives have been accepted by the 7 key levels regarded as the framework of SFM on a global scale, which were 
listed as follows: Extent of forest resources; biodiversity; health and vitality of forest ecosystems; protective functions of forests; productive functions of forests; socioeconomic functions; and legal, policy and institutional framework (Castañeda 2000; Grainger 2012; Siry et al. 2005).

Biodiversity criteria and indicators, which are among the referred key levels, have become one of the most widely discussed criteria and indicators since the Rio Summit. Even today, there are efforts made for developing the indicators related to these criteria (Kotwal 2008). In its simplest definition, biodiversity means the diversity of vitality, i.e. life. Life on the Earth as well as anything related is encompassed by this definition. Whereas, in the definition adopted at the Rio Summit in 1992 and used in the Biodiversity Convention, there is mentioned that the diversity of living organisms, the ecological (terrestrial, nautical and aquatic) environments where those organisms live and the ecological processes supported by those environments. This also encompasses the diversity within and between species and ecosystems (Claridge et al. 1997). When biodiversity is defined in this manner, it is rather difficult to study this concept and generate something with it. Therefore, scientists benefit from the levels of biodiversity for expressing and describing biodiversity (Gaston 1996). Despite the absence of a single accepted definition of biodiversity, biodiversity levels are accepted by nearly all experts.

Biodiversity levels vary within a large spectrum extending from genetic materials to the ecosystems encompassing the abiotic environment sheltering the species. Genetic structure, which is main component of vitality, constitutes the basis of these levels. Genes are followed by species and ecosystems are composed using interrelations among species at higher levels (Moser et al. 2002). In other words, biodiversity is composed of different elements such as genetics, species, ecosystem diversity and ecological processes (Kaya \& Raynal 2001). The most important issue related with the preservation of biodiversity and its sustainable use consists in the obligation to make a quantitative evaluation regarding biodiversity (Duelli \& Obrist 2003). Therefore, when leaving the field scale to move to a regional, national or global scale, the only criteria that may be used are the number of species, the number of endemic species and threats on species. By using the geographic information systems and computer facilities developed recently, it has become possible to widen the databases related with these three indicators and conduct evaluations on wider fields (McGeoch 1998; Ulgen \& Zeydanli 2008)

As a result of the international processes and agreements it is affiliated with, Turkey has initiated efforts for designating SFM criteria and indicators with the initiatives commenced by the General Directorate of Forestry (GDF) in 1999 (Akyol 2004). To serve this purpose, the set of criteria and indicators designated in the Pan-European Process and the Near Eastern Processes have been compiled into a set of criteria and indicators applicable at a national level. GDF has tested this set in consequent years and finalized the set of criteria and indicators within a series of studies. However, the set of criteria and indicators adopted by GDF is composed solely of the criteria and indicators included into the sphere of responsibilities of GDF. This set has not been shaped according to the realities and social structure of Turkish forestry (Akyol \&Tolunay 2006). GDF's initial set and its current version in terms of biodiversity indicators are presented in Table 1 (Akyol 2009).

The assessment of Table 1 shows that the biodiversity criterion expressed with 11 indicators in the initial set is expressed using 4 indicators in its current version. Eight indicators, which were included into the initial set (distribution of forest ecosystems, reserves and protected areas, rare endangered ecosystems, forest-dependent species, at-risk species in the forest areas, mixed stand, species dependent on forests with a decreasing range and population levels in the range of major species) have been omitted from monitoring studies in the current version. The

TABLE 1. Biodiversity indicators of GDF

\begin{tabular}{lcl}
\hline & Initial Set \\
\hline Criteria & Indicators & Description \\
\hline Biodiversity & 1 & Distribution of forest ecosystems \\
& 2 & Reserves and protected areas \\
3 & Fragmentation status of forest resources \\
4 & Rare endangered ecosystems \\
5 & Forest-dependent species \\
6 & At-risk species in the forest areas \\
7 & Mixed stand \\
8 & Reliability of natural regeneration \\
9 & Seed sources \\
& 10 & Species dependent on forests with a \\
& & decreasing range \\
& 11 & Population levels in the range of major \\
& species \\
\hline
\end{tabular}

\begin{tabular}{lcl}
\hline & \multicolumn{2}{c}{ Current Version } \\
\hline Criteria & Indicators & Description \\
\hline Biodiversity & 1 & Fragmentation status of forest resources \\
& 2 & Silvicultural treatments \\
& 3 & Reliability of natural regeneration \\
& 4 & Seed sources \\
\hline
\end{tabular}

Source: Akyol 2009 
indicator of silvicultural treatments has been added to the current version.

In the assessment of the indicators detected in the monitoring studies, it is worth noting that in the current version, GDF has significantly narrowed the monitoring scope especially in terms of biodiversity (genetic, species, ecosystems diversity and ecological processes). Due to these reasons, this study has aimed at developing the biodiversity criteria and indicators for SFM efforts in Turkey.

\section{MATERIALS AND METHODS}

\section{MATERIALS}

The indicators on protecting, developing and sustaining biodiversity, which are among Turkey's SFM criteria and indicators, compose the main material of the study. The primary data of the study have also been obtained from the survey conducted across Turkey. The secondary data of the study are composed of the information obtained from literature analyses as well as the information, documents and reports obtained from various public entities and organizations.

\section{METHODS}

Global and Turkish forestry literature have been screened and assessed for the study and relevant information, statistics, reports and similar documents have been collected from relevant national and international organizations and evaluated as well. After that, the questionnaire forms prepared were sent to the employees of the Ministry of Forest and Water Affairs (MEF) (GDF personnel, the personnel of research directorates and the personnel working in other ministerial units). Moreover, the questionnaires was also sent to the forestry faculties of universities and forestry-related NGOs (Chamber of Forest Engineers of Turkey, Foresters Association of Turkey, Turkish Foundation for Combating Soil Erosion, for Reforestation and the Protection of Natural HabitatsTEMA, Central Union of Turkish Forestry CooperativesORKOOP, Nature and Environment Foundation-DOCEV, Association of the Research of Rural Environment and Forestry Problems).

In total, 534 questionnaire forms were returned from relevant entities and organizations and evaluated. The statistical package program Statistical Package for the Social Sciences (SPSS) has been used in the evaluation of the questionnaires data (SPSS 1988). The evaluation on whether the biodiversity indicators of the survey respondents are adequate has been done using the Kruskal Wallis test. The Kruskal Wallis test is a test inspecting whether more than two samples, whose variances are not equal and do not have a normal distribution, carry the same characteristics, and is used for non-parametric unidirectional variance analysis (Sheskin 2000; Steel \& Torrie 1980).
A survey has also been conducted at the local interest groups (forest villagers, shepherds, heads of local authorities and administrators of other public entities and organizations) at the regional levels within the scope of the study.

\section{RESULTS AND DISCUSSION}

At the beginning the survey, respondents were asked to score the criteria for designating their overall perspectives on SFM criteria and indicators. Thus, respondents were asked to rank the criteria upon giving a scope of 6 for the most important criterion and a score of 1 to the least important criterion. However, the objective was not to prioritize the criteria but to designate the tendencies of the respondents on the criteria and to evaluate their proposals. In the assessment of Figure 1, it is observed that the respondents of the questionnaire gave nearly the same scores for the criteria. This demonstrates that equal importance is placed on all criteria. However, although the criteria scores are approximately at the same level, it is noteworthy that the biodiversity criterion is placed on the top with $17.32 \%$, showing that the respondents place importance to the development of the indicators below this criterion.

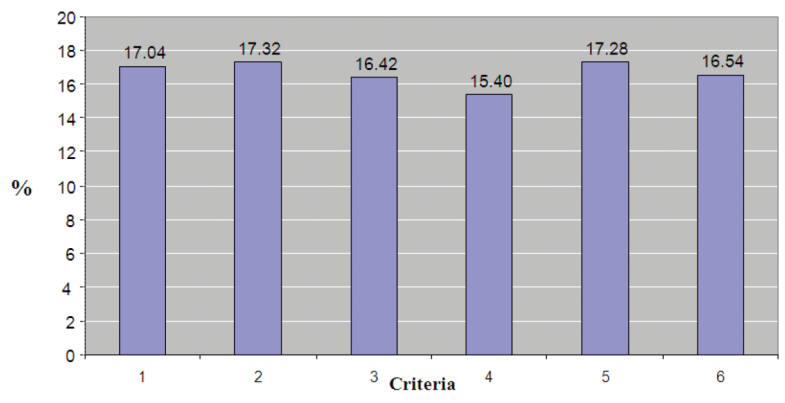

FIGURE 1 . Trends in the criteria

1: Forest Resources, 2: Biodiversity, 3: Health and Vitality, 4: Production Capacity and Functions, 5: Protective and Environmental Functions, 6: Socio-economic Functions

The importance placed by the respondents to the indicators below the criterion of biodiversity in the survey is shown in Figure 2.

In the assessment of Figure 2, the indicator of silvicultural treatments is observed to be an important indicator with $26.62 \%$. This is followed by the indicator of seed sources $(26.25 \%)$, the indicator of reliability of regeneration $(25.93 \%)$ and finally the fragmentation status of forest resources $(21.20 \%)$.

At this point, it is worth noting the high level of the relative importance of the indicators of silvicultural treatments and seed sources. Silvicultural processes utilized in forest ecosystems have a direct impact on the ecosystem processes and may even lead to positive or negative impacts extending to species and genetic diversity 


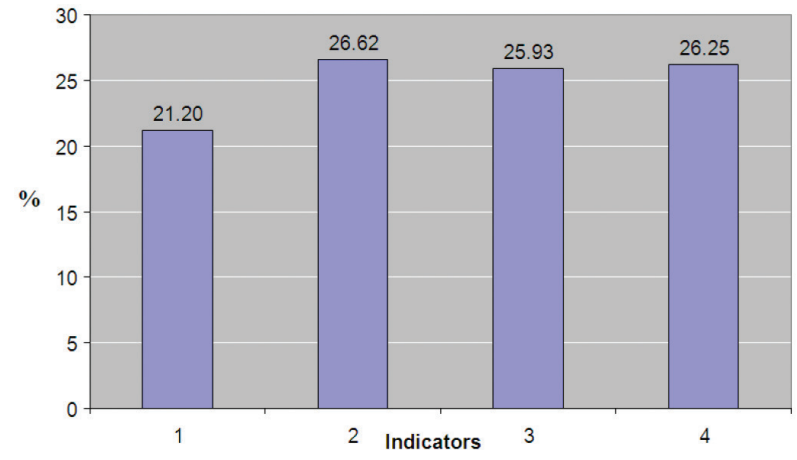

FIGURE 2. Percentages of importance of the indicators under the criterion of biodiversity

1: Fragmentation status of forest resources, 2 : Silvicultural treatments, 3 : Reliability of regeneration, 4: Seed sources

in some cases. Likewise, seed sources are areas with good genetic properties in the forest ecosystems, allocated for serving silvicultural purposes. These areas are places offering important services for protecting, sustaining and developing biodiversity. The referred properties of the indicators have an impact on the high level of their relative importance.

Figure 3 presents the assessment of survey respondents regarding the indicators which they believed measured under biodiversity. The evaluation of Figure 3 demonstrates that 118 out of 534 survey respondents $(22.10 \%)$ believe that it is not necessary to measure the indicator of fragmentation status of forest resources. This is in line with the phenomenon related with the indicator on the fragmentation status of forest resources in Figure 2. In Figure 2, the indicator of fragmentation status of forest resources is an indicator regarded as relatively least important.

However, the assessment of the questionnaire findings shows that respondents face certain ambiguities in terms of what the indicator on the fragmentation status of forests means; the study shows that the definitions relating to indicators are not sufficient and that respondents are not sufficiently informed about the degree of fragmentation. The degree of fragmentation should be designated in detail. Because the condition of fragmentation creates a positive status up to a certain degree especially for the wildlife, it may leave a negative impact on the forest ecosystem beyond a certain degree. The degree of fragmentation may vary due to different ecological structures. Therefore, it will be more rational to work on the administrative unit level in order to designate this degree. However, considering the social and economic condition of Turkey, it is highly important to conduct the work for designating the degree of fragmentation at least on a regional level.

The assessment of the other indicators not being regarded as necessary to be measured in Figure 3 shows that these are respectively the indicator of silvicultural treatments $(8.05 \%)$, indicator of reliability of regeneration $(6.55 \%)$ and the indicator of seed sources $(3.37 \%)$. The fact that these rates are extremely low implies that it is necessary to continue measuring all biodiversity indicators.

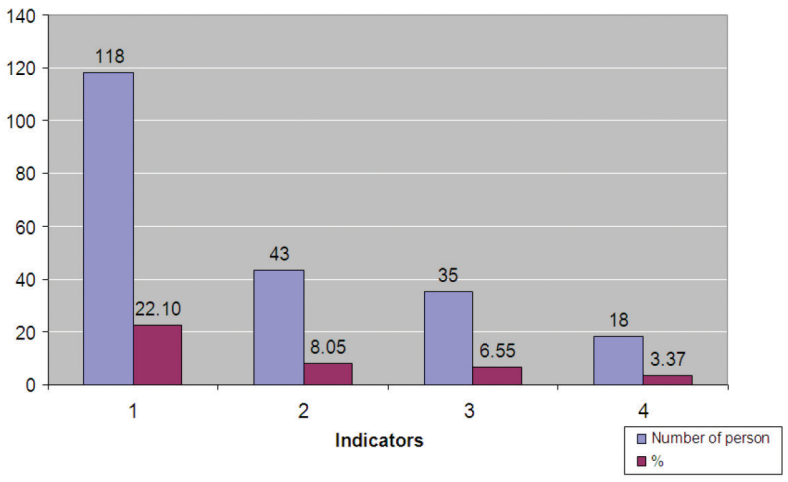

FIGURE 3 . Indicators that are not required to be measured within the scope of the indicator of biodiversity

1: Fragmentation status of forest resources, 2: Silvicultural treatments, 3: Reliability of regeneration, 4: Seed sources

Figure 4 shows the evaluations made by the participants of the study, relating to the indicators which they believe are difficult to measure in terms of the criterion of biological diversity. As seen in Figure 4, the indicators believed to be difficult to measure are respectively, the indicator of the reliability of regeneration $(22.10 \%)$, the indicator of the fragmentation status of forest resources $(14.23 \%)$, the indicator of silvicultural treatments $(8.99 \%)$ and the indicator of seed sources $(2.62 \%)$.

Considering the assessment of the data sources of these indicators under the criterion of biodiversity, the indicator of seed sources is the most convenient monitor indicator in terms of the convenience in finding data and making measurements. The indicator of reliability of regeneration is an indicator based on particular data; however it cannot be expressed quantitatively within this scope. In this respect, it is expected to be positioned at the top in terms of the difficulty in measurement. Considering of the initial set and the current situation as well, it is worth noting that serious problems are faced in terms of the difficulty in measurement in the criterion of biodiversity.

The respondents were finally asked to evaluate whether the criteria and indicators of GDF are adequate

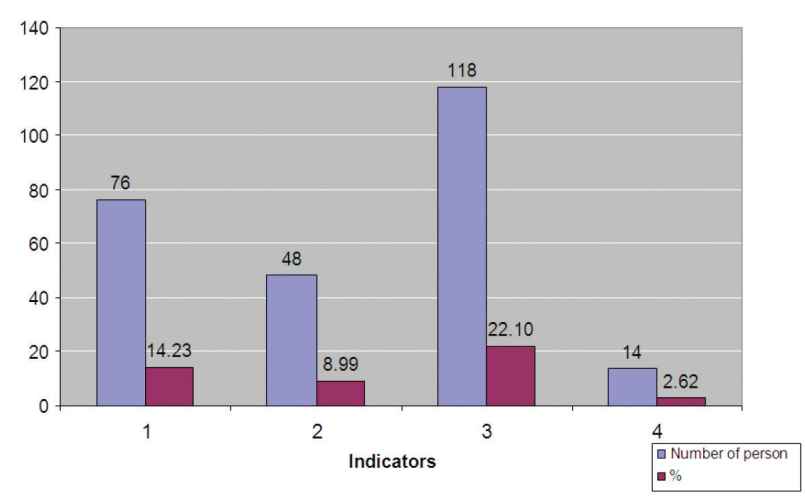

FIGURE 4. Indicators believed to be difficult to measure within the scope of the criterion of biodiversity

1: Fragmentation status of forest resources, 2: Silvicultural treatments, 3 : Reliability of regeneration, 4 : Seed sources 
or not. The Kruskal Wallis test was used in the statistical evaluation of the answers to this question. The approaches of the respondents relating to this question are provided in Table 2. The assessment of Table 2 shows that $11.8 \%$ of survey respondents regard the current criteria and indicators as adequate while $61.8 \%$ regard it as partially adequate. Only $26.4 \%$ of the respondents regard the current set as adequate. Therefore, this reflects key tips on the need to develop the current criteria and indicators.

The differences in average ranks in the Kruskal Wallis test performed for the responses given by the survey respondents to the GDF SFM criteria are not statistically significant. In other words, there are no groups among the groups participating in the survey that have a different view on the topic of adequacy. As observed in Table 2, all groups regard the GDF SFM criteria and indicators as partially adequate.

The above mentioned topics, outputs of global meetings (CCFM 2004; EFI 2001)' the evaluation of relevant literature (Nilsson 2001; Prabhu et al. 1998; Stork et al. 1997) and especially the indicators relating to the biodiversity criterion shaped by the proposals of the survey respondents are presented in Table 3 .

The criterion of biological diversity is a criterion taking, base on the protection (Hagan \& Whitman 2006), development and maintenance of biodiversity possessed by forest ecosystems as a basis (Büchs 2003; Pearson 1994) and the assessment of Table 3 shows that there are 13 indicators proposed for this purpose.

The study aimed at demonstrating the indicator of forest areas according to tree species, the distribution of forest areas according to tree species and time-dependent changes (Noss 1999). This is an indicator which may be used at the national and forest management unit level (Mitchell \& Joyce 2000) and the use of hectare (ha) is suitable as a unit of measure.

Using the mixed stands indicator, it is aimed to designate the species constituting the mixture in forest areas and to trace time-dependent changes. Differently from the distribution of forest resources included into the criterion of forest resources, the mixture rates $(\%)$ are requested in this indicator. It is an indicator which may be used at the national and forest management unit level.

Using the endemic species indicator, it is aimed to designate the status of endemism in terms of biodiversity. This indicator may be used at the national and forest management unit level. However, tracing local differences is also an important indicator in terms of biodiversity at the management unit level. Using this indicator, it is aimed to trace the number and areas of endemic species in terms flora and fauna as well as the data relating to the population status. However, the effective tracing of this indicator depends on the inventory work to be performed. $\mathrm{Ha}$, items and the density in the unit area (item/ha) may be used as a unit of measurement (Lindenmayer et al. 2000; Miles 2002).

The indicator of endangered species expresses the species, which have remained in an area much smaller than their natural dispersion areas, have lost a major portion of their genetic variation and facing the threat of losing their current existence. Using this indicator, it is aimed to trace the population status of these species, their past and current dispersion areas and similar data and to reveal the changes that occurring with time. The effective tracing

TABLE 2. Approaches of respondents relating to the adequacy of criteria and indicators of GDF

\begin{tabular}{lcc}
\hline Adequacy & Item (Frequency) & Percentage $(\%)$ \\
\hline Adequate & 141 & 26.4 \\
Partially Adequate & 330 & 61.8 \\
Inadequate & 63 & 11.8 \\
Total & 534 & 100 \\
\hline
\end{tabular}

TABLE 3. Biodiversity criteria and indicators obtained from the survey

\begin{tabular}{lll}
\hline Biodiversity & \multicolumn{1}{c}{ Indicators } \\
& 1. & Forest areas according to tree species \\
2. & Mixed stands (mixture rates and areas) \\
3. & Endemic species (flora-fauna, population status) \\
4. & Endangered species (flora-fauna, population status) \\
5. & Seed sources (seed stands, seed gardens, clone gardens, gene protection forests) \\
6. & Special protection areas (no. and areas) \\
7. & Areas for protecting, developing and producing wildlife (no. and areas) \\
8. & Wetland (flora and fauna variety, no. and areas) \\
9. & Delicate and rare ecosystems (varieties and areas) \\
10. & Fragmentation status of ecosystems (no. of fragments and areas) \\
11. & Rate of regeneration (natural-artificial) and degree of success \\
12. & Silvicultural treatments (silvicultural treatment areas and varieties) \\
13. & Overused species (Herbal species-Animal species) \\
\hline
\end{tabular}


of this indicator depends on inventory work. This is an indicator, which may be effective while revealing the local differences especially at the forest management unit level in addition to its utilization at the national level.

Using the seed sources indicator, it is aimed to designate the areas with genetically good characteristics and to trace time-dependent changes. Seed stands, clone gardens, the number of gene preservation forests and areas are traced for this purpose. This is an indicator, which may be used at the national and forest management unit level.

The indicator of special protection areas is an indicator proposed to be used in the designation of the special areas where preservation is required for the flora and fauna in the forest resources and tracing time-dependent changes. This indicator aims to trace the number of these areas, their field and the species are located in these areas. It is an indicator, which may be used at the national and forest management unit level.

The indicator on the protection, development and production areas for wildlife is an indicator proposed for tracing the developments in the field of wildlife. Using this indicator, it is aimed to trace the changes number of areas allocated for this purpose and the changes occurring with time. This is an indicator that may be utilized at the national and management unit level.

The wetland indicator aimed to designate the wetland located within the forest resources and to trace these areas within time. Using this indicator, it is proposed to designate the number of these areas, the fields they occupy and the diversity of the flora and fauna. However, the effective tracing of this indicator depends on the inventory work to be conducted. This is an indicator which may be effectively used in showing the differences at the forest management unit level and may also be utilized at the national level.

Using the indicator on delicate and rare ecosystems, it is aimed to designate the delicate and rare areas that may be impacted especially from the forestry applications at the forest management unit level and to trace time-dependent changes. Thus, it will be possible to go outside the production areas for the conservation and development of this type of areas and act more carefully in the applications.

The fact that forest areas are divided independently into small fragments creates positive impacts up to a certain degree in terms of wildlife; however it may lead to negative impacts in terms of the other ecological process in the forest ecosystem. For example, very small fragments in the forest areas may lose their activities in terms of natural regeneration. Fragmentation is composed of natural factors (fire, geological-scale changes on earth) and anthropogenic factors (main electrical lines and water channels). The measurement of these areas may be performed in terms of the number of forest fragments in different area classes and the average distance between these fragments. The utilization of satellite-aided geographic information systems facilitate tracing in the measurements. GDF has composed 3 categories for the size of forest fragments in the evaluations (small fragments smaller than 10 ha, fragments between 10 and 99 ha and big sizes larger than
$100 \mathrm{ha}$ ). This is an indicator which may be used as an effective tracing tool especially at the forest management unit level.

The indicator on the regeneration rates (naturalartificial) and the success rates is an indicator proposed for tracing the status of the regeneration interventions made on the forest ecosystems. Using this indicator, it is aimed to trace the proportion of the regeneration area to the total rate of forest and regeneration area in relation with categories. This is an indicator, that may be used at the national and forest management unit level. Ha and percentage rates may be used as a unit of measurement.

The silvicultural treatments indicator is an indicator proposed for tracing the silvicultural treatments made on the forest ecosystems and shows time-dependent changes. The silvicultural treatments made on forest ecosystems and the regeneration treatments made on forest ecosystems mentioned in the previous indicator are technical implementations directly impacting the ecological processes in the forest ecosystems. This implementations may even give rise to changes at the level of genetic and species diversity. Due to these reasons, indicators aiming to trace the silvicultural treatments made on the forest ecosystems are proposed in this study. The types of silvicultural treatments and the designation of areal distributions may be traced within time at the forest management unit and national level.

The indicator of overused species is an indicator proposed for the purpose of making evaluations on the areas where vegetal and animal species are used in a manner disrupting the balance of ecological processes and the species used. Designation of the areas and species, which are open to such type of abuse in forest resources, if any and tracing the changes appearing in time are important in terms of the balances of forest ecosystem equilibrium. The indicator may be used at a national level. However, its use at the forest management unit level may provide the possibility to conduct a more effective tracing.

\section{CONCLUSION}

Forest resources have been operating in forestry for years, when continuity has been understood. However, this understanding of continuity has continued only as the continuity of producing the raw material wood and the fact that the forest is a complex ecosystem that has always been neglected. The development models used in the economic system have destroyed forest resources in time and narrowed their limits. Being faced by this situation, humankind has questioned the economic development models being used and tried to develop new development models. The sustainable development model arising in this process carries the developmental purpose of not harming the environment and highlights the need to utilize renewable natural resources for this purpose. Forest resources are ranked at the top among renewable natural resources. Based on this concept, humankind stated that the road to sustainable development passes through sustainable 
forestry and the concept of SFM as top global agenda item, has been brought since the beginning of the ' 90 s.

Many studies have been initiated at an international and regional level for ensuring SFM and designating the criteria and indicators to be used for this purpose, more than 150 countries across the world have been included into these studies. Upon signing various international agreements, Turkey has become a party in the process of designating the SFM criteria and indicators, which began in the ' 90 s. Many countries have designated their criteria and indicators, started to monitor their forests and even certified their forest resources within the ongoing process. In order to fulfill SFM, GDF has prepared an initial set by compiling the criteria and indicators defined in the Pan-European and Near East Processes in 1999. Within the ongoing process, efforts have been made to adapt this set to conditions of relevant countries with the studies made on the initial set.

The consideration of the SFM criteria and indicators at a global level demonstrates that the interest on forest resources is mostly related with the services to be provided by forests rather than the wood production to be achieved via forests. Within this scope, it is observed that the forest ecosystem and the maintenance and development of the biodiversity within this system are among the mostly accentuated criteria among regional processes.

The measurability of the indicators proposed in the study is among the topics most open to criticisms. For instance, the criterion of biodiversity cannot be measured as the studies required for many indicators (such as endemic species and the population status of endangered species) have not been conducted. However, we should not forget that the indicators proposed in the study are basic indicators and they have been prepared upon considering the indicators regarded as basis in the international arena and the views and proposals of the academicians working on this topic and the GDF personnel included these studies for the purpose of establishing the basis of the forest administration units. The measurability of the indicators and their degree of importance are actually showed at the management unit level or the regional level. For example, due to the suitability of the data in a specific region, many indicators relating to biodiversity may be measured. However, due to failure to find suitable data in another region, these indicators may not be measured. In this case, by stating that the indicators under biodiversity cannot be measured and omitting them from tracing efforts would not be a suitable approach.

Due to above mentioned reasons and based on the findings of the studies, in terms of the SFM model, it will be able to take the criteria and indicators proposed in this study as basis in the consequent studies for designating regional or management unit level. The designation of the criteria and indicators at the regional or forest management unit level and the revelation of their degree of importance and scalability with various analyses will also enable the presentation of a SFM model that takes into account economic, ecological and social differences for Turkish forestry.
In this study which aimed to designate the SFM biodiversity indicators at the national level for Turkey, the criteria and indicators emerging from global studies and meetings have been taken as a basis. Consequently, the knowledge and experience of the GDF employees conducting the SFM work across Turkey in the last decade and of the other interest groups have tried to be obtained via a questionnaire. As a result of a series of analyses and evaluations, there are 13 indicators that may be used as a basis at the regional or forest management unit level for the purpose of protecting, developing and maintaining biodiversity for Turkey.

\section{ACKNOWLEDGEMENTS}

This study is the summary of a section of the $\mathrm{PhD}$ thesis entitled 'Turkish Model of the Criteria and Indicators for Sustainable Forest Management' prepared in the Department of Forest Engineering, Graduate School of Applied and Natural Sciences of Suleyman Demirel University. The study has been supported by the Coordination Unit of Scientific Research Projects of Suleyman Demirel University, Project No: 1524-D-07.

\section{REFERENCES}

Akyol, A. 2009. Sustainable Forest Management Criteria and Indicators and the Present Situation of Turkey. II. Socio Economic Issues Congress in Forestry, SDU Forestry Faculty, Isparta. pp. 36-46.

Akyol, A. 2004. Principles, Indicators and Applications of Sustainable Forest Research Management in Turkey. SDU Natural and Applied Sciences, Master's Thesis, Isparta. pp. 1-131 (unpublished).

Akyol, A. \& Tolunay, A. 2006. Principles, indicators and applications of sustainable forest research management in Turkey. SDU Journal of Natural and Applied Sciences 10(2): 221-234.

Brand, D.G. 1997. Criteria and indicators for the conservation and sustainable management of forests: Progress to date and future directions. Biomass and Bioenergy 13(4): 247-253.

Büchs, W. 2003. Biodiversity and agri-environmental indicatorsgeneral scopes and skills with special reference to the habitat level. Agriculture, Ecosystems \& Environment 98(1): 35-78.

Brang, P., Courbaund, B., Fisher, A., Kissling-Näf, I., Pettenella, D., Schönenberger, W., Spörk, J. \& Grimm, V. 2002. Developing indicators for the sustainable management of mountain forests using a modelling approach. Forest Policy and Economics 4: 113-123.

Castañeda, F. 2000. Criteria and indicators for sustainable forest management: International processes, current status and the way ahead. Unasylva 51(203): 34-40.

Castañeda, F., Palmberg-Lerche, C. \& Vuorinen, P. 2001. Criteria and Indicators for Sustainable Forest Management: A Compendium. Forest Management Working Paper No 5. Forest Resources Development Service, Forest Resources Division, FAO, Rome.

CCFM. 2004. Defining Sustainable Forest Management in Canada Criteria and Indicators 2003. Technical Supplement 1, Detailed Indicator Descriptions, Canadian Council of Forest Ministers (CCFM). pp. 1-56. 
Claridge, M.F., Dawah,H.A. \& Wilson, M.R. 1997. Species: The Units of Biodiversity. London: Chapman \& Hall.

Duelli, P. \& Obrist, M.K. 2003. Biodiversity indicators: The choice of values and measures. Agriculture, Ecosystems \& Environment 98(1): 87-98.

Farrell, E.P., Ryan, D., Andersson, F., Hüttl, R. \& Piussi, P. 2000. European forest ecosystems: Building the future on the legacy of the past. Forest Ecology and Management 132: 5-20.

EFI. 2001. Criteria and Indicators for Sustainable Forest Management at the Forest Management Unit Level. March 2000, EFI Proceedings No 38, Nancy, France. pp. 21-25.

Gaston, K.J. 1996. What is Biodiversity? Biodiversity: A Biology of Numbers and Difference. London: Blackwell Scientific Publications.

Grainger, A. 2012. Forest sustainability indicator systems as procedural policy tools in global environmental governance. Global Environmental Change 22(1): 147-160

Hagan, J.M. \& Whitman, A.A. 2006. Biodiversity indicators for sustainable forestry: Simplifying complexity. Journal of Forestry 104(4): 203-210.

ITTO. 2005. Revised ITTO criteria and indicators for the sustainable management of tropical forests including reporting format. ITTO Policy Development Series No 15.

ITTO. 1992. Criteria and indicators for the measurement of sustainable tropical forest management. ITTO Policy Development Series No. 3.

Kaya, Z. \& Raynal, D.J. 2001. Biodiversity and conservation of Turkish forests. Biological Conservation 97(2): 131-141.

Kotwal, P.C., Omprakash, M.D., Gairola, S. \& Dugaya, D. 2008. Ecological indicators: Imperative to sustainable forest management. Ecological Indicators 8(1): 104-107.

Lindenmayer, D.B., Margules, C.R. \& Botkin, D.B. 2000. Indicators of biodiversity for ecologically sustainable forest management. Conservation Biology 14(4): 941-950.

McDonald, G.T. \& Lane, M.B. 2004. Converging global indicators for sustainable forest management. Forest Policy and Economics 6(1): 63-70.

McGeoch, M.A. 1998. The selection, testing and application of terrestrial insects as bioindicators. Biol. Rev. 73: 181-201.

Mendoza, G. \& Prabhu, R. 2000. Development of a methodology for selecting criteria and indicators of sustainable forest management: A case study on participatory assessment. Environmental Management 26(6): 659-673.

Miles, P.D. 2002. Using biological criteria and indicators to address forest inventory data at the state level. Forest Ecology and Management 155(1): 171-185.

Mitchell, J.E. \& Joyce, L.A. 2000. Applicability of Montreal process biological and abiotic indicators to rangeland sustainability: Introduction. The International Journal of Sustainable Development \& World Ecology 7(2): 77-80.

Moser, D., Zechmeister, H.G., Plutzar, C., Sauberer, N., Wrbka, T. \& Grabherr, G. 2002. Landscape patch shape complexity as an effective measure for plant species richness in rural landscapes. Landscape Ecol. 17: 657-669.

Mrozek, T., Balsillie, D. \& Schleifenbaum, P. 2006. Field testing of a criteria and indicators system for sustainable forest management at the local level. Case study results concerning the sustainability of the private forest Haliburton Forest and Wild Life Reserve in Ontario, Canada. Forest Policy and Economics 8: 593-609.

Nilsson, S. 2001. Forest Policy, Criteria and Indicators, and Certification. Interim Report IR-01-024. International Institute for Applied Systems Analysis, Laxenburg, Austria.
Noss, R.F. 1999. Assessing and monitoring forest biodiversity: A suggested framework and indicators. Forest Ecology and Management 115(2): 135-146.

Pearson, D.L. 1994. Selecting indicator taxa for the quantitative assessment of biodiversity. Philosophical Transactions of the Royal Society of London. Series B: Biological Sciences 345(1311): 75-79.

Prabhu, R., Maynard, W., Atyi, R.E., Colfer, C.J.P., Shepherd, G., Venkateswarlu, P. \& Tiayon, F. 1998. Testing and Developing Criteria and Indicators for Sustainable Forest Management in Cameroon: The Kribi Test Final Report. Center for International Forestry Research (CIFOR), Indonesia. pp. $1-122$.

Purnomo, H., Mendoza, G.A. \& Prabhu, R. 2004. Analysis of local perspectives on sustainability forest management: An Indonesian case study. Journal of Environmental Management 74: 111-126.

Rametsteiner, E. 2001. SFM indicators as tools in political and economic contexts: Actual and potential roles. In Criteria and Indicators for Sustainable Forest Management, edited by Raison, R.J., Brown, A.G. \& Flinn, D.W.IUFRO 7 Research Series. New York: CABI Publishing. pp. 107-130.

Sheskin, D.J. 2000. Handbook of Parametric and Nonparametric Statistical Procedures. 2nd ed. Boca Raton, Florida: Chapman $\&$ Hall/CRC press

Siry, J.P., Cubbage, F.W. \& Ahmed, M.R. 2005. Sustainable forest management: Global trends and opportunities. Forest Policy and Economics 7(4): 551-561.

SPSS. 1988. User's Guid. 3rd ed. Chicago-USA: SPSS Inc.

Steel, R.G.D. \& Torrie, J.H. 1980. Principles and Procedures of Statistics: A Biometrical Approach. 2nd ed. New York: McGraw-Hill Inc.

Stork, N.E., Boyle, T.J.B., Dale, V., Eeley, H., Finegan, B., Lawes, M., Manokaran, N., Prabhu, R. \& Soberon, J. 1997. Criteria and Indicators for Assessing the Sustainability of Forest Management: Conservation of Biodiversity. Center for International Forestry Research (CIFOR), Working Paper No 17. pp. 5-6.

Ulgen, H. \& Zeydanli, U. 2008. Forests and Biodiversity. Ankara: Nature Conservation Centre. pp. 1-200.

Wiersum, K.F. 1995. 200 years of sustainability in forestry: Lessons from history. Environmental Management 19(3): 321-329.

Wolfslehner, B., Vacik, H. \& Lexer, M. 2005. Application of the analytic network process in multi-criteria analysis of sustainable forest management. Forest Ecology and Management 207: 157-170.

Faculty of Forestry

Suleyman Demirel University

32260 Cunur Isparta

Turkey

*Corresponding author; email: ahmettolunay@sdu.edu.tr

Received: 2 May 2014

Accepted: 4 August 2014 